Problems of World Agriculture volume 18 (XXXIII), number 4, 2018: 162-174 DOI: 10.22630/PRS.2018.18.4.107

Kinga Gruziel $^{1}$, Małgorzata Raczkowska ${ }^{2}$

Warsaw University of Life Sciences - SGGW, Poland

\title{
The Taxation of Agriculture in the European Union Countries
}

\begin{abstract}
The paper sets out the key principles for taxation of agriculture in selected European Union countries. The theoretical foundations of tax systems in the context of their functions and features specified as desirable in the literature are discussed. EU agricultural taxation systems are presented in reference to optimisation and tax competitiveness. Some shared features of these agricultural taxation systems were pointed out and their division in two basic models (the British model and the continental model), which was presented taking as example the countries in which these models operate. Taxation of income derived from agricultural business activity is a natural direction of changes in tax systems. The tax policy implemented in the European Union countries in relation to agriculture make use of the principle of tax justice to the highest possible extent. The diversity of the tax rules and structures applied in the EU makes it possible to tax agricultural income without limiting the development potential of agricultural enterprises (farms), and often stimulates them. The form of individual tax systems results from numerous economic, social and political circumstances. Special tax treatment of agriculture is expressed through tax construction elements, e.g. right to deduct the value of generated loss or investment expenditure from taxable income.
\end{abstract}

Key words: tax, taxation of agriculture, agricultural tax

JEL Classification: E62, H24, Q1

\section{Introduction}

The diversity of tax systems in EU countries results in compiling and comparing conditions for functioning and running a business. Various tax constructions and varied taxation rules under the same taxes result in competition for production factors. In most EU Member States, the current agricultural taxation systems are the consequence and effect of their evolution. In spite of noticeable variances, tax systems have many features in common, which stems from the nature and definition of tax as a historical category linked to the theory of statehood and private ownership (Krajewska, 2012). Taxation of agriculture is an aspect of tax policy understood as a means of influencing the state in such a manner as to ensure budget income enabling the pursuit of economic and social objectives. If they are of purely economic nature they relate, among other things, to the creation of material grounds for economic development and welfare of our society. Social objectives concern the creation of conditions for: equal opportunities in getting jobs and remuneration which correspond to qualifications, in securing an adequate level of education, professional promotion and potential for running a business. Tax policy can also be directed negatively, the extreme expression of which is a threat to taxpayers' freedom (restriction of their subjective rights), depreciation of tax justice and, as a result, a reduction in the welfare of citizens.

${ }^{1} \mathrm{PhD}$, Department of Economics and Economic Policy, WULS - SGGW, 166 Nowoursynowska St., 02-787 Warsaw, e-mail: kinga gruziel@sggw.pl; https://orcid.org/0000-0003-2429-3795

${ }^{2} \mathrm{PhD}$, Department of Economics and Economic Policy, WULS - SGGW, 166 Nowoursynowska St., 02-787 Warsaw, e-mail: malgorzata_raczkowska@sggw.pl; https://orcid.org/0000-0002-8540-8958 
In the literature on the subject we find a clear specification of the notion of tax included in its definition. Taxes are assigned with specific social and economic functions realised to varying degrees. Regardless of the intensity of tax impact and the degree of performance of its various functions, the objective of tax, which Gaudemet (2000) defines as coverage of public burdens, is unchanged. Taxes are the primary source of government income (fiscal function) and the scope of tax income exceeds receipts from other sources, such as charges, duties and loans. Their relevant regulatory function consists in the redistribution (distribution) of national income and wealth between taxpayers and publiclaw units, i.e. the state and local government bodies. Their stimulus function, on the other hand, stands for making use of tax instruments to induce some specified actions of individuals and to shape the direction and pace of their development. Taxes, by performing informative functions, make it possible to draw conclusions on regularities or irregularities taking place in the course of economic processes.

Grądalski (2006) distinguishes the objectives of tax systems operation through the prism of a state model. He distinguishes two models: the first one is based on the welfare economy, where the state is an advocate of social interest, and the other one - on the institutional economics, which assumes that the state maximises its own utility by by limiting general social needs. This division stays in line with the state's fiscal, redistributive and regulatory objectives. Currently, in the literature on the subject, the range of functions attributed to taxes is even wider, and the following functions: fiscal, redistributive, regulatory, simulative and controlling are treated as equally relevant.

The fiscal function of taxes aims to provide income to the state, and its importance results from the fact that taxes are the key source of state budget income and the grounds of its operation. It is believed that taxes are the most effective method of influencing business entities. Their redistributive function results from the fiscal function and has a derivative nature in relation to it. The obtained tax income is allocated by the state or local government for the performance of particular public tasks, which enables the division of national income and wealth between citizens and public-law units.

Today's efficient tax system has five characteristics which are regarded as desirable taxation principles (Stiglitz, 2015):

- economic efficiency; the tax system should not cause distortions in the economy, ensuring an efficient allocation of resources and increasing their economic efficiency;

- administrative simplicity; resulting in a low level of operational and management costs of a given tax system;

- flexibility; enabling to efficiently respond to changes in farming conditions,

- political accountability; a tax system should be clear and transparent;

- fair treatment of individuals who are part of a given tax system; which it is understood as similar treatment of people in a similar situation and the imposition of higher taxes on entities who are able to bear higher tax burdens.

Rulings on the optimisation of taxation from the point of view of the official apparatus refer to the Laffer curve theory, which is based on that there are two different rates of taxation giving the same amount of tax revenue. It is important to note that a different economic standing of the budget is due to various tax collection costs. The theory of optimal taxation indicates dependencies between a level of tax receipts and arrangements adopted under an agreement concluded between taxpayers and the State. The theory of optimisation assumes the maximisation of social welfare with given tax receipts and 
through the minimisation of tax enforcement costs. Thus, the minimisation of tax enforcement costs (tax collection) stands for additional welfare losses, which reflect costs resulting from a change in price relations as a result of taxation (Gruziel, 2012).

Taking into account the welfare economy and its principles, in relation to estimating the optimal level and structure of production, but also tax burdens, most economists accept the Pareto criterion. Decisions and solutions in line with this principle aim to improve the standing of a given social group without worsening the one for others (Stiglitz, 2015).

The key objective of the European Union's tax policy is to strive to create conditions which are conducive to the establishment of rational tax systems. According to Szczodrowski (2007), a rational tax system is characterised by: proportional participation of individuals in burdens related to the performance of state functions, moderate level of taxes and low costs of their acquisition, objectivity in the imposition and collection of taxes, adjustment of payment conditions to taxpayers' capabilities and compliance of taxes with the ethical principles advocated by the society.

The aim of this paper study is to determine the principles and scope of the taxation of agricultural enterprises (farms) in some selected European Union countries. The key patterns of taxation and the most relevant tax constructions in agriculture of the EU countries are presented. For the purposes of the analysis, a deliberate selection of the countries being the subject of deduction was made. The diversification of assumptions and operational aspects of agricultural taxation was the criterion of this selection. The analysis was made on the basis of the available literature on the subject on the subject of research. Below the general principles of taxation of agriculture in the EU and taxation schemes on income derived from agricultural activity are presented. Two current models of income taxation were presented: taxation based on general rules and preferential taxation.

\section{Literature review}

In the literature on the subject, agricultural taxation is treated in two ways. Agricultural economists raise the specificity of the agricultural sector (e.g. seasonality, spatiality, conditioning by biological and natural factors) as a distinguishing feature of this segment of the economy. Increasingly, the contemporary theories treat agriculture as an integral part of the process of economic growth. In most developed countries, tax reforms have been pursued to adapt their legislation to the today's economic realities. The assumed effect was to simplify and reduce the number of taxes, reduce a level of their rates and broaden the tax base. However, preferential treatment of agriculture in tax terms is justified by the dependence of agricultural production on natural and climatic factors (Gruziel, 2008).

Taxation of agriculture is a relevant aspect of the taxation policy being a method for the state to influence subordinate food business entities so as to ensure that budget revenues are sufficient to fulfil its economic and social objectives. Tax systems play an important role in economic processes influencing the condition of entities participating in the management process and stimulating the competitiveness of a given country through, among others: supporting the development of its selected economic sectors, supporting savings of resources and household savings (Rosiński, 2008).

The specific conditions of agricultural activity are conducive to the formulation of numerous theories on the manner and scope of taxation of this segment of the economy. The applied range of tax constructions seems to depend to the furthest on: the relevance of 
agricultural production in a given country's economy, climatic and natural conditions, degree of technological advancement and structure of a given tax system. In practice, the agricultural taxation model in the EU usually consists of two charges (taxes) on income, wealth or property used for agricultural activities. The application of such models is justified by the specificity of agriculture, where the factors of production: land, labour and capital are of paramount importance. Taxation of land take the form of a uniform tax on land or several property taxes (usually wealth). Work and capital in combination with the factor of land manifests itself as an agricultural activity and its effect, i.e. income or revenue, is subject to taxation.

The harmonisation of taxes is a measure aimed at achieving the relative uniformity of tax systems. Oręziak (2007) defines tax harmonisation as solutions in-between the non-binding coordination of national tax regulations and their complete harmonisation in all the EU Member States. The full harmonisation of tax systems is not a target for the EU, mainly due to the varied national interests of individual countries. Such harmonisation is designed to minimise potential distortions in the operation of the Community market. It may apply to both the rates and principles of estimating the tax base. Divergences in the design of tax systems became even more pronounced upon the EU enlargement and coordination of tax policies has become necessary to promote employment growth while ensuring the sustainability of fiscal income (Gruziel, 2008). Bearing in mind the phenomenon of this tax law harmonisation in the EU, the majority of farmers in Poland assess negatively any changes in the tax system, mainly fearing the potential occurrence of formal difficulties in keeping accounting records and increasing their tax burden (Kubot, Czubak, 2016). According to farmers, changes in the taxation of agricultural enterprises (farms) should include a valuation of labour costs incurred by farmers and their families (Ganc, Mądra, 2011). In addition, tax changes in agriculture could favour the harmonisation of business taxation rules and contribute to enhancing the efficiency of fiscal tax functions (Wasilewski, Gruziel, 2008).

The analysis of the EU tax systems shows that tax competition is an integral part of market economy which, by stimulating innovation, results in lower prices, higher quality and wider access to goods and services (Oręziak, 2007). The creation of two types of competition is also a relevant aspect. Increased capital mobility and searching for optimal taxation conditions may be a manifestation of the struggle for a potential investor and capital serving the development of the state. In the group of tax income beneficiaries there is a kind of 'rivalry' in the access to public financial resources between and among many local government units and public institutions.

In the EU countries, farmers are generally subject to the same tax regulations as other social and professional groups. Agricultural activity is chiefly subject to income tax on generated income, and different construction solutions result in lower fiscal burdens. Agriculture in the EU benefits from tax preferences based on the specificities of production, but also makes use of specific solutions applied in non-agricultural sectors. Agricultural taxation systems focus mainly on the taxation of agricultural income, agricultural property, goods and services (Wasielewski, Mądra, Ganc, Gruziel, 2015).

\section{Models of taxation agriculture in the EU}

Agricultural tax applies in many EU countries and is an element of the tax system in force in a given country. A characteristic feature of agricultural tax is that it is not linked to 
potential or actual agricultural income, but to agricultural activity. There is a variety of different definitions of agricultural activity in the EU legislation, but reference to the concept of economic activity and linking it to land used for agriculture is their shared feature. The structures used in the EU are of various nature: income tax, wealth tax, revenue tax, production tax and mixed form (Podstawka, 1995). The common principle is to treat agricultural tax as an instrument of economic, economic and fiscal policies, among others, by shaping a level of income generated by farmers.

In most of the EU countries, agricultural taxation systems are not separated from other systems in place in a given country. Income from agricultural activities is subject to taxation. Due to the specificity of agriculture, there are constructions often used to reduce the tax burden borne by farmers.

In the EU, farmers' income was originally taxed according to the wealth scheme, with average income determined on the grounds of their area or stock of animals owned. This kind of taxation system corresponded to the original nature of agriculture. Nowadays, agricultural enterprises (farms) got transformed into specialised production companies which has contributed to the abandonment of the wealth structure of agricultural tax. Agricultural tax is differentiated by the adoption of different rules for determining the tax base or different definitions of revenues and costs.

In the EU countries there are two models of agricultural taxation: British and continental. The British model is characterised by taxation of agricultural activity, in principle with income tax, in the same manner as non-agricultural economic activity is taxed. This model is in force in countries with high land concentration by a small group of entities. Under this model, it is possible to apply separate regulations affecting the final shape of the tax base (e.g. varied determination of the value of stocks). It should be stressed that land used only for agricultural activity is excluded from property tax. The continental model is characterised by taxation of agricultural activity by means of one contribution in the form of wealth tax or revenue-income tax. The model prefers to charge a single tax on both the wealth (assets) used in agricultural production and the income derived from agricultural production. In the continental model there are two forms distinguished: simplified and mixed. The simplified form applies two taxes: income tax and tax on land used for agricultural production. The tax base is determined on the grounds of the estimated standards or cadastral income methods. The mixed continental model also uses two taxes on income and on land used for agricultural production. Two different methods of determining income are used in this model. The differences in the applied methods result not from the nature of business, but from its range. Simplified income determination methods (flat-rate deductible costs, income estimation standards, cadastral income method) are used for small-scale agricultural production. Then for larger-size agricultural activity real methods are used to determine income.

Przygodzka distinguishes the application of two taxation models in the EU (2006): income from agricultural activities is treated on an equal footing with other income and different rules for calculating income from agricultural production. A lack of obligation to keep accounts is an important feature of agricultural taxation systems in most of the EU countries; still the countries apply a system of incentives to keep accounts (e.g. the right to deduct costs of accounting services from revenue).

In EU agricultural taxation models, when taxing income, net income, understood as revenue from agricultural activity minus costs incurred in connection with running an agricultural enterprises (farms), is considered to be the tax base. In most of the European 
countries, unlike in the Polish tax system, aid received from both the national and EU budgets is included in the tax base.

In the EU countries there are three most important structures on burdening agriculture. The first group consists of income taxes, including personal income tax on natural entities and corporate tax on legal entities. A direct reference to economic surplus in the form of earned income is a characteristic feature of income taxes. Wealth taxes forming the second group include: property tax, ownership transfer tax and sales tax. In addition, the EU systems have taxes on holding wealth or part of it (on properties, agriculture) and on increase in property (on inheritances and donations). The third group of EU tax constructions consists of indirect taxes, with the most effective and harmonised VAT.

\section{Taxation of agricultural income on the general principles}

In the group of the EU countries where agricultural taxation is subject to the general rules, the United Kingdom and Ireland can be mentioned. In the English tax system, income from agricultural activity is not treated preferentially and agricultural enterprises (farms) are not subject to specific tax rules. There is no precise definition of income under this legal system. The method of determining the tax base for agricultural activity is the same as in the case of economic activity, i.e.: gainful occupation, production, trade, economic enterprise. The existing categories of revenue are included in six schedules defined by symbols A to F, initially subject to proportional tax and then to progressive tax. Under the British tax law, agricultural activity is included in schedule D1, i.e. it is classified as a commercial activity. Tax rates depending on a level of the achieved income range from $20 \%$ to $40 \%$.

Farmers in the UK are treated equally to other taxpayers in fiscal matters. They enjoy the right to reduce their income by statutory amounts, but also, like other entrepreneurs, they are obliged to keep accounts. Net income adjusted for agricultural production costs makes the taxable amount of agricultural activity. The accounts make the grounds for determining farmers' income and their tax due to the state budget.

Agricultural activity in accordance with the law consists in taking over, in whole or in part, land for agricultural purposes (plant cultivation, breeding or animal husbandry). Agricultural income is determined on the basis of the accounts. The accounts must show all income for a given period of time and all costs incurred by the taxpayer. It is also the taxpayer's responsibility to consider the opening and closing balance sheets for of inventories. The time at which revenue arises is determined on the basis of the accrualbased approach. From 2013, entities with a turnover of less than $£ 150,000$ can use the cash accounting approach. Tax deductible costs are expenses incurred in full and exclusively for conducting agricultural activity. Taxpayers are entitled to deduct expenses incurred before the start of their business activity and related to it. In addition, taxpayers are entitled to deduct side costs related to agricultural activity, e.g. charges, commissions related to obtaining a loan or letting land. Costs incurred for training sessions, research studies, staff renumeration, charitable donations, social security contributions, etc. are deductible. Other regulations apply to animal breeders and keepers; the legislator specifies the number and principles of determining the value of a flock of animals and the principles of taxation. British farmers make depreciation write-offs on their real estate investments at an annual rate of $4 \%$ of the value of such investments made, with a maximum duration of 25 years. 
Taxpayers are entitled to deduct losses provided that their activity is gainful rather than hobby and an additional condition is that such losses have not been recorded within the previous five years.

The legislator provides for averaging taxable income (the amount obtained prior to deduction of loss and depreciation write-offs), provided that in two consecutive years the difference in income achieved in one year is higher than $70 \%$ of income in the following year. This solution brings averaged income, which excludes the taxpayer's use of the cash accounting approach. On the other hand, agricultural properties (lands and buildings), if used for agricultural activity, are exempt from taxation.

In Ireland, as in the United Kingdom, agricultural income is treated in the same way as income from other sources and is subject to personal income tax. Farmers who are natural entities pay personal income tax if their agricultural enterprise (farm) is operated as an business unit and their income is subject to corporate income tax. Agricultural enterprises (farms) run in the form of partnerships are not subject to taxation, as such, and the income of individual shareholders is subject to taxation.

In the Irish tax system, taxable income is grouped into four main schemes:

- C: interest,

- D: income derived from property, trade, business activities, income not included in other schemes,

- E: income derived from employment, pensions,

- F: income obtained from the state budget.

Personal income tax is charged on all income earned by natural entities and partners in partnerships. The basic personal income tax rate is $20 \%$ and the increased rate is $42 \%$. The amount of income taxed at the standard rate depends on the status of a given natural entity. Income in excess of certain amounts is subject to the increased rate. Tax due from natural entities is reduced by the tax-free amount, the amount of which depends on the category of a given taxpayer (individual taxpayers, spouses settling taxes jointly). Ireland has adopted the British principle of paying tax - PAYE (pay as you earn). Employee's tax is deducted by his/her employer. Self-employed persons conducting independent economic activity are obliged to pay taxes through a self-accounting system.

Persons conducting agricultural activities are obliged to keep the accounts, but they do not have to be kept by qualified accountants. It is the taxpayer's duty to prepare inventory at the end of the accounting period (inventory at the end of the tax year). The value of stocks is determined on the basis of acquisition cost or net value on sales. The tax preference stands for a relief from an increase in the value of stocks. It is due when the value of stocks at the end of the accounting period is higher than at the beginning of the accounting period. It is calculated at less than or equal to $25 \%$ of the amount representing an increase in stocks, but not more than EUR 15000 in the subsequent years. An increase in this relief up to a $100 \%$ increase in stocks is available to young farmers, with a limit of EUR 40,000 in one year and EUR 70,000 in four consecutive years. This deduction is treated as a cost prior depreciation write-offs. Farmers, like other groups of taxpayers, apart from the amount exempt from taxation, are entitled to benefit from child-raising allowances.

In the group of additional tax benefits for farmers in Ireland, a reduction in taxable income from the purchase of farm buildings ( $15 \%$ of total expenditure over six consecutive years and $10 \%$ in the seventh year), a reduction in tax due to the taxpayer's low income, health and age is foreseen. Farmers making pro-ecological investments may benefit from 
additional tax instrument in the form of up to $50 \%$ deduction of their costs incurred for such investments, the amount of which may not exceed EUR 50 000. The Irish legislation provides an incentive for transferring agricultural enterprises (farms) to young farmers. For a period of four years upon the transfer of land, the farmer is entitled to $100 \%$ inventory allowance. The Irish tax system also provides for a tax preference for farmers who reduce their emission of pollutants into the environment. Farmers with waste management plans are especially under this ecological policy. In the first year, farmers may deduct $50 \%$ of their expenses incurred. The remaining value of capital expenditure may be written off for seven consecutive years. Costs of storage, water and slurry are classified under this group of expenses.

\section{Preferential tax treatment of agricultural income in the EU}

Austria, Germany and Italy are among the EU countries where preferential tax treatment of agriculture has been applied. Under the Austrian tax system, income from agricultural activities conducted by a natural entity is subject to personal income tax. Agricultural activity is subject to income tax according to the progressive scale, and the income tax rates are within $0-50 \%$. Agricultural enterprises (farms) with legal personality are subject to corporate income tax at the rate of $25 \%$.

Under the taxation of agricultural activities in Austria, all income received, defined as the value of income less costs incurred in order to obtain such income and special deductions is subject of taxation. The Austrian law provides for the tax base to be determined on the basis of complete tax documentation, provided that the turnover in two consecutive years is at least EUR 550000 and the value of a given agriculture enterprise (farm) on 1 January of the tax year exceeds EUR 150 000. Simplified accounts is the primary form of preference for agricultural enterprises (farms) with their lower revenue level and less estimated value. The second group of agricultural enterprises (farms) benefiting from this preference includes units with their estimated value of between EUR 130000 and EUR 150 000, while their turnover generated over two consecutive tax years is within EUR 400000 and EUR 550 000. Agricultural enterprises (farms) in this group keep the simplified records of revenues and tax deductible costs and, secondly, may apply the cash accounting approach. The third group of agricultural enterprises (farms) may determine their income on the lump sum basis. Provided, however, the value of such unit is below EUR 130000 and the turnover in subsequent years does not exceed EUR 400000. When these figures are exceeded, it automatically makes it necessary to run the full accounting. The estimated value of such unit is determined by the relevant tax authorities on the basis of the applicable rules and standards. Holders of low-value agricultural enterprises (farms) can opt for the flat-rate form of settlement of their income obtained. The taxpayer may opt not to use this flat-rate form, but it results in that he/she may not use it for five consecutive years. The alternative is to apply the full flat-rate approach, which is dependent on the value of a given agricultural enterprise (farm), the area of cultivated agricultural land and the number of livestock.

Property tax in Austria is charged on agricultural and forestry assets and set at the federal level, but constitutes the income of municipalities. The value of land determined on the basis of the comparative method with respect to the reference farm (for which the value of yields per 1 ha is EUR 2 400) make the grounds for taxation. The legislator provides for 
exceptions for e.g. agricultural enterprises (farms) with their reduced production value, or lands where horticultural crops, vineyards or forestry activities are run. The system for determining the tax base is complicated and may range from $1.6 \%$ but may not exceed $500 \%$, and the tax rates are set by individual municipal councils.

In the German tax system there is a construction of agricultural tax based on the income category. Tax preferences relating to agriculture concern, among others, bookkeeping, exclusions and reductions in tax rates. The German legislation lists seven main sources of revenue, the income from which is subject to personal income tax, including agricultural and forestry activities. In order for a taxpayer's agricultural activity to be considered subject to personal income tax, it must be undertaken and conducted with a view to making a profit, performed on a self-employed basis, be continuous and be linked to participation in general economic transactions. Revenue obtained by the taxpayer will be considered as coming from agricultural production, when activity will consist in the development of lands as part of the primary production (using natural factors, i.e. land and natural forces). Under production, the taxpayer should obtain products of agricultural origin intended for sale or further production (feed). When it refers to the construction of the German income tax on agricultural activity, the condition for being subject to taxation of income derived from cultivation or animal husbandry is a link between production and agricultural land. Having as much farmland to be able to provide sufficient food for the held number of animals in an imperative condition. The legislator specified limits in the construction of income tax stating that - depending on the area of an agricultural enterprise (farm), the taxpayer may raise a certain number of animals expressed in so-called livestock units. When these limits are exceeded, it will result in its recognition as non-agricultural economic activity.

Income from agricultural and forestry production include, among others, revenue from the cultivation of horticultural plants, fruit-growing plants, vines, livestock breeding and land use. In Germany, income tax paid by farmers is a construction based on progressive rates.

The German tax system provide for support for agriculture through special systems of estimation of income derived from agricultural activity, rules of keeping accounts and exclusions and reductions in tax rates. Income from agricultural activity can be determined according to three methods:

- on the basis of the accounts kept (income being the difference between the assets of a given unit at the end of the current year and its assets at the end of the previous year, adjusted for any reductions or increases, as appropriate); this requirement applies to taxpayers engaged in agricultural activities in respect of transactions subject to or exempt from VAT with an annual turnover exceeding EUR 600 000, or with a value of land used for agricultural production exceeding EUR 25 000, or with income derived from agricultural activities exceeding EUR 60 000;

- on the basis of owned resources, the so-called simplified accounts; farmers determine their income by decreasing their revenues by incurred expenses; all expenses incurred for agricultural activity, except for private expenses, are deductible;

- on the basis of the linear method, the application of which depends on: a number of animals held by a given agricultural enterprise (farm) may not exceed 50 livestock units, the total area of land (not exceeding $20 \mathrm{ha}$ ); the total amount of income (higher than EUR 900 and not exceeding EUR 30 700); 
- Income is determined by multiplying the area of lands forming a given agricultural enterprise (expressed in hectares) by the officially determined amount, amounting to EUR 350 in 2017.

In Germany, income from the taxation of agricultural activities is usually determined using the straight-line method, which is due to the fact that when this solution is applied income is lower than the amount calculated on the basis of the accounts.

The German tax system has the progressive tax scale and tax rates range between 0 and $45 \%$. The tax-free amount applicable to all taxpayers, including farmers is in operation, but its level differs depending on the category of taxpayer. Preferential systems of incentives based, among others, on enabling farm owners to deduct costs related to accounting services also apply in German agriculture.

Property tax in Germany brings income for municipalities; (the capitalised value of 'pure' income makes the tax base of land forming an agricultural enterprise (farm). This category is determined on the basis of the comparative method and the tax rate is determined by municipalities.

Income derived from running agricultural activities in Italy enters the group of categories being subject to income tax, but is treated in a preferential manner. Taxable income is determined in a separate, more favourable manner than is the case for other income.

In Italy, taxable income is divided into six categories:

- income from property ownership, including income from agriculture and forestry,

- income from capital investments,

- income from service-based relationship

- income from the provision of services and business activities,

- income from trade and industry,

- income from other sources.

Income obtained by entities for conducting agricultural activities in Italy is classified as property income. Among them the following were distinguished: income derived from land, agricultural income and income from derived from buildings. Such income is cadastral-based, i.e. assigned to land or building entered into the land cadastre.

Income obtained through conducting taxable agricultural activity consists of income derived from land and agricultural income. Income derived from land does not consider the nature of run agricultural activity, since under the Italian tax system land which was entered in the land cadastre generates income. The area of agricultural lands in Italy is divided into cadastral districts to which individual municipalities are assigned. The location of agricultural lands, their classification into cadastral districts, the purpose for which they are to be used and the class of lands determine the estimated amount of tax attributed.

Agricultural income being taxable on the basis of running agricultural activity is determined when this activity engages the capital and labour of a given entity and includes operations falling within the definition of agricultural activity. Agricultural income, just like income from land, is averaged. The difference is that land is involved in activities including capital and labour actor within the limits of this land 'capacity'. In line with the Italian legislature agricultural activity covers all activities conducted in conjunction with an agricultural enterprise (farm) such as: activities directly related to land or forestry; animal husbandry if at least $25 \%$ feed comes from own crops; activities related to crop production and activities related to the storage, processing and sale of agricultural and zootechnical products. 
Under the Italian tax system, as of 2016, lands owned by agricultural entities are exempt from property tax. The tax-free amount for the Italian taxpayer is approximately EUR 8,000. Income taxpayers, including farmers, may deduct the following allowances related to the subsistence of family members (wives and minor children) from their taxable income:

- expenses for spouse and dependent children - up to EUR 800 for spouse and EUR 800 for dependent children (a spouse and dependent child is a person who has not exceeded income of approximately EUR 3000 per year),

- expenses related to the taxpayer's medical treatment in excess of approximately EUR 150 euro - 19\% of such expenses,

- credit interest for the purchase of a flat,

- life and accident insurance,

- costs in the field of secondary and higher education and further training courses,

- expenditure on sports activities of children and youth aged 5-18.

Analysing the shape and changes which were introduced in the systems of agricultural taxation in the EU, a tendency can be perceived to eliminate a separate source of income from taxation of agricultural activity and to include it in income from non-agricultural activity. In addition, there is a noticeable trend in individual countries to align the rules on taxation of agricultural activities with the rules on taxation of economic activities. Most of the EU countries use the mixed continental model to harmonise and increase the competitiveness of their tax systems.

Assessment and perception of the systems by taxpayers is a relevant aspect of international comparisons (apart from to the construction of tax systems). In the EU countries reaching a higher level of development than Poland, the applied tax solutions not always face taxpayers' favourable assessment and no objection. More than half of them consider the national tax system to be inefficient and in need of immediate reform. Farmer's opinions indicate a rather unfavourable standing towards the taxation system, even though special provisions are in force to support agriculture (subjective average assessment based on a group of several dozen German farmers - sufficient). It may be surprising that in countries where such support is not provided or is limited to a minimum and farmers themselves are treated on an equal footing with taxpayers working in other sectors of the economy, assessments on tax systems and their operation are more favourable (subjective average assessment based on a group of several dozen Swedish and Greek farmers - good). Farmers, often considered to be a social group with insufficient education, are well-aware of changes to be made in order to improve the tax system for their activities. They include, among others: reduction in a number of taxes forming the system, taxation of income derived from agricultural activity or introduction of additional controls on public officials and their competences (Kisiel, Idzikowski, 2014).

\section{Conclusions}

The paper presents a series of models of agricultural taxation in operation in some selected countries of the European Union, taking into account detailed solutions on agricultural enterprises (farms). On the basis of the conducted research studies, the following conclusions were formulated: 
1. Similar income tax systems are applied in the analysed EU countries. As a general rule, income from agricultural activities is subject to income tax and variances if they occur relate to the solutions adopted for determining income. A level of detailing of the very definition of agricultural activity for tax purposes varies.

2. In most of the EU countries, agricultural enterprises (farms) are run in the form of family farms without legal personality, and personal income tax is their dominant tax. The current solutions confirm the equal treatment of farmers and other taxpayers in fiscal matters. This confirms the groundlessness of treating agriculture as an economic enclave. Bearing in mind the specific nature of agricultural production and its dependence on natural and climatic conditions, tax systems have preferential constructions, such as the right to deduct the value of generated losses or capital expenditure from taxable income.

3. Simplified form of accounting is the most commonly used form of preference in the EU tax systems. Under the EU tax structures, support for agriculture is not limited to tax exemption, but consists in the introduction of certain facilitations and improvements which motivate taxpayers in order to, among others, increase their economic activity.

\section{Referenses}

Andersen, F.G., Asheim, L.J., Mittenzwei, K., Veggeland, F. (2002). Taxation of Agriculture in selected countries. Study of United States, Canada, Australia, Germany, United Kingdom, Ireland, France, Switzerland, and Italy with relevance to the WTO. Norwegian Agricultural Economics Research Institute, Oslo.

Bouvier, M. (2000). Wprowadzenie do prawa podatkowego i teorii podatku (The introduction to tax legislation and tax theory). Biblioteka Przeglądu Podatkowego, Warszawa.

Ganc, M. Mąra, M. (2011). Sprawiedliwość opodatkowania rolnictwa oraz możliwości zmian w tym zakresie w opinii rolników indywidualnych (Fairness of taxation of agriculture and the possibility of changes in this regard in the opinion of farmers). ZN SGGW Ekonomika i Organizacja Gospodarki Żywnościowej, 89, 207-218.

Gruziel, K. (2008). Stan i kierunki zmian w opodatkowaniu gospodarstw rolniczych (The state and the directions of changes in the taxation of agricultural farms). Wydawnictwo SGGW, Warszawa.

Gruziel, K. (2012). Koszty procesu fiskalnego podatku rolnego na przykładzie gminy wiejskiej (The fiscal cost process and agricultural tax: a rural county example). RN SERiA, 14(3), 100-103.

Hybka, M. (2005). Opodatkowanie dochodów osób fizycznych w Republice Federalnej Niemiec (The taxation of personal income in the Federal Republic of Germany). Wydawnictwo Akademii Ekonomicznej w Poznaniu.

Kulawik, J., Lelong, P.Y., Pawłowska-Tyszko, J., Soliwoda, M. (2013). Systemy podatkowe w krajach Unii Europejskiej (The tax systems in European Union countries). Instytut Ekonomiki Rolnictwa i Gospodarki Żywnościowej - PIB, Warszawa.

Kisiel, R., Idźkowska, K. (2014). System opodatkowania rolnictwa w Polsce oraz w wybranych krajach Unii Europejskiej. The system of agriculture taxation in Poland and chosen countries of the European Union. $Z N$ SGGW Polityki Europejskie, Finanse i Marketing, 12(61), 64-78.

Krajewska, A. (2012). Podatki w Unii Europejskiej (The taxes in the European Union). PWN, Warszawa.

Kubot, A., Czubak, W. (2016). Perspektywa wprowadzenia podatku dochodowego w rolnictwie w ocenie rolników (The perspective of an implementation of the income tax in agriculture in the assessment of farmers). Journal of Agribusiness and Rural Development, 2(40), 335-344.

Oręziak, L. (2007). Konkurencja podatkowa i harmonizacja podatków w ramach Unii Europejskiej. Implikacje dla Polski (The tax competition and harmonization in tax on the European Union. The implications for Poland). Dom Wydawniczy ELIPSA, Warszawa.

Pawłowska-Tyszko, J., Soliwoda, M. (2014). Dochody gospodarstw rolniczych a konkurencyjność systemu podatkowego i ubezpieczeniowego (The incomes of agriculture farms and competitiveness of the tax system and insurance system). Instytut Ekonomiki Rolnictwa i Gospodarki Żywnościowej - Państwowy Instytut Badawczy, Warszawa. 


\section{K. Gruziel, M. Raczkowska}

Podstawka, M. (1995). Opodatkowanie rolnictwa i perspektywy jego zmian w Polsce (The agriculture taxation in Poland and outlook for change). Wydawnictwo SGGW, Warszawa.

Przygodzka, R. (2006). Fiskalne instrumenty wspierania rolnictwa - przyczyny stosowania, mechanizmy i skutki (The fiscal instruments to support agriculture - reasons for, mechanisms and effects). Wydawnictwo Uniwersytetu w Białymstoku.

Rosiński, R. (2008). Polski system podatkowy. Poszukiwanie optymalnych rozwiązań (The Polish tax system. The finding best solutions). Centrum Doradztwa i Informacji Difin Sp. z o.o., Warszawa.

Serowa, E., Khramowa, I., Maslenkowa, U. (2000). Taxation in Agriculture, Institute for the Economy in Transition, Moscow.

Smoleń, P. (red.) (2018). Opodatkowanie rolnictwa w Polsce. Weryfikacja założeń. Perspektywa zmian (The agriculture taxation in Poland. The assumption verifications. The prospects a changes). Wydawnictwo C.H. Beck, Warszawa.

Stiglitz, J.E. (2015). Ekonomia sektora publicznego (Economics of the public sector). Wydawnictwo Naukowe PWN, Warszawa.

Szczodrowski, G. (2007). Polski system podatkowy (The Polish tax system). Wydawnictwo Naukowe PWN, Warszawa.

Wasilewski, M., Gruziel, K. (2008). Podatek rolny a podatek dochodowy - konsekwencje zmian dla gospodarstw rolniczych (The farming and income tax in agricultural farms - consequences of changes). Roczniki Nauk Rolniczych, seria G, 94, 115-129.

Wasilewski, M., Mądra-Sawicka, M., Ganc, M., Gruziel, K. (2015). Finansowe skutki wprowadzenia podatku dochodowego $\mathrm{w}$ indywidualnych gospodarstwach rolniczych (Financial effects of the income tax implementation in farms). Wydawnictwo SGGW, Warszawa.

\section{For citation:}

Gruziel K., Raczkowska M. (2018). The Taxation of Agriculture in the European Union Countries. Problems of World Agriculture, 18(4), 162-174; DOI: 10.22630/PRS.2018.18.4.107 